\title{
FACTORS ASSOCIATED WITH SELECTION OF NON-IUD CONTRACEPTIVE IN WOMEN OF REPRODUCTIVE AGE IN SEMARANG, CENTRAL JAVA
}

\author{
Imelda Margaretha Saragih, Suharto, Arwinda Nugraheni, \\ Dodik Pramono, Arufiadi Anityo Mochtar
}

Faculty of Medicine, Universitas Diponegoro

\begin{abstract}
Background: Data from the Health Office of North Semarang in 2012 showed that Bandarharjo village had the largest number of contraceptive users, which was predominated by non-IUD contraceptive users (84.8\%). Little is known about factors associated with the selection of non-IUD contraceptive in women of reproductive age in Indonesia. The aim of this study was to analyze factors associated with the selection of non-IUD contraceptive in women of reproductive age.

Subjects and Method: This was an analytic observational study with a crosssectional design. This study was conducted at Bandarharjo village, Semarang, Central Java, from June to September 2017. A sample of 66 contraceptive users was selected by simple random sampling. The dependent variable was the use of non-IUD contraceptive. The independent variables were women's knowledge, attitude, education, family income, belief, number of children, husband support, exposure to family planning information, cultural tradition, and health insurance status. The data were collected by a set of questionnaire and interview. Chisquare test was employed to run bivariate analysis.

Results: The selection of non-IUD contraceptive was associated with women's age $(\mathrm{OR}=1.35 ; 95 \% \mathrm{CI}=0.98$ to $1.85 ; \mathrm{p}=0.045)$, knowledge $(\mathrm{OR}=1.33 ; 95 \% \mathrm{CI}=$ 0.99 to $1.79 ; \mathrm{p}=0.049)$, and attitude $(\mathrm{OR}=1.35 ; 95 \% \mathrm{CI}=0.98$ to $1.85 ; \mathrm{p}=0.001)$, and it was statistically significant. The selection of non-IUD contraceptive had no statistical significant association with education, economic status, culture tradition and belief, number of children, experience, and husband support.

Conclusion: The selection of non-IUD contraceptive has statistical significant association with women's age, knowledge, and attitude, but it has no statistical significant association with education, economic status, culture tradition and belief, number of children, experience, and husband support.
\end{abstract}

Keywords: non-IUD, contraceptive, associated factors, reproductive age.

\section{Correspondence:}

Arwinda Nugraheni. Faculty of Medicine, Universitas Diponegoro. Jl. Prof. H. Soedarto, SH., Tembalang, Semarang 50275. Email: arwinda46@yahoo.com. Mobile: 02476928010. 